\title{
Innovation in Family Business Syllabus: The Case of the American University in Cairo
}

\author{
Dr. Ashraf Sheta ${ }^{1}$ and Dr. Ahmed El Gallad ${ }^{2}$ \\ ${ }^{1}$ Adjunct Assistant Professor, School of Business, The American University in Cairo, Egypt \\ ${ }^{2} \mathrm{CEO}$, El Gallad Company, Cairo, Egypt \\ *Correspondence: Dr. Ashraf Sheta, ashrafsheta@aucegypt.edu
}

\begin{abstract}
Teaching family business has been trending in some European and American business schools. This trend has very limited existence in all Egyptian, and Arab business schools. This manuscript presents the experience of the family business course at American university in Cairo (AUC) which started in 2017, and is still in the evolution phase in spring 2020. The article starts by shedding light on the concept of family business, and its importance in the economy. This is followed by addressing the literature of family business education on the global level, and its status in Egypt, and the Arab world. Moving forward to the micro level of the AUC, through discussing the origins of the family business course inception as a pillar in the school of business strategy, and then the evolution of the syllabus from spring 2017 till spring 2020. The details of the course from pedagogy to assessments, guidelines, and rubrics are explained.
\end{abstract}

KEYWORDS: Family business, Teaching Pedagogy, Family business education, Rubrics, Guidelines

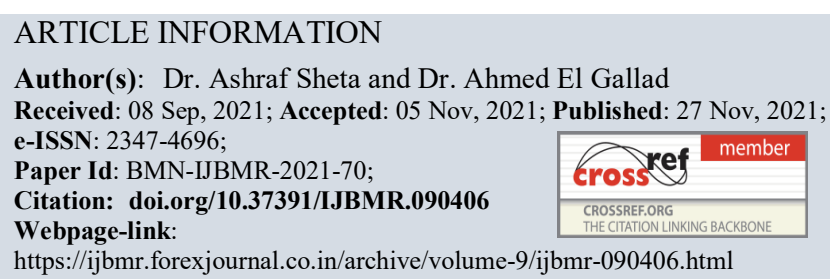

\section{INTRODUCTION}

\subsection{Purpose of the study}

The purpose of this paper is to provide a holistic analysis to the evolution of family business, as a field of study in Egypt. This analysis is presented through shedding light on the evolution of family business study in the field of academe in general. This study is expected to exhibit the experience of inception, and delivery family business in the American University in Cairo to be the first business school in Egypt to teach this course. Through this leading step, the paper discusses the learnt lessons since 2017, the beginning of teaching the family business subject, as well as the challenges faced throughout the journey. This will help in creating future opportunities to widen the base of studying family businesses and to increase the awareness of its importance. Teaching family business is still in its infancy. This study is considered the first of its kind that highlights the importance of including family business in the programs of the business schools in Egypt.

\section{BACKGROUND}

\subsection{Particularity of family business: A comparative} analysis

According to Dawson \& Mussolino, (2014). Family engagement in the firm, according to researchers, is what distinguishes a family business from others (Miller \& Rice, 1967). The majority of researchers consider family engagement to be about ownership and management (Handler, 1989). Churchill and Hatten (1987) prefer to include the fact that a family successor exists. Even the CEO of a publicly traded corporation is occasionally influenced by his or her spouse and children, so no business is immune from family involvement.

It's simple to operationalize definitions based on the components of family involvement: management, ownership, governance, and succession. They are unable to do so, unfortunately, when one firm considers itself a family business and the other does not, distinguish between the two enterprises with the same level of family engagement. As a result, there is a need to construct a definition that reflects the essence of the family business and can be utilized to identify the family business from the non-family firm in theory, research, and practice (Chrisman \& Sharma, 1999).

Beyond this components-of-involvement approach (Chrisman, Chua, \& Sharma, 2005), what truly distinguishes a family business is its basic essence and core features, which form its unique and distinctive identity. Given that enterprises with similar levels of family involvement in ownership and management may or may not believe themselves to be or behave like family businesses, capturing their distinct behavior is critical (Chua et al., 1999). Carney (2005) coined the term "particularism" to describe how owners of family businesses see the company as theirs and intervene in business decisions using altruism or nepotism in addition to (or instead of) rational-cause reasoning.

\subsection{Family business education worldwide}

After World War II, the main focus in business education was on large corporations (Sharma et al. 2007). During that period, scholarly attention on family business studies was not existent. This did not prevent family firms from growing and playing an important role in world economies through providing job opportunities and contributing to GDP. Thus the educational needs for family businesses remained unaddressed. The first real attempt to establish family business as a field of managerial study came from family business practitioners - 
family business owners and consultants. Those three parties collaborated in developing family business centers and professional associations which provided space for groups focused on serving educational needs for family business stakeholders. During the late seventies, the family business centers role began to be noticed through imposing family business topics on universities centers which are positioned on the edge of business schools focusing on executive education. The second element for founding the family business education was the professional associations (Sharma et al. 2007). After their retirement, several entrepreneurs decided to search for family business succession in different venues, including academe. Those entrepreneurs devoted their time and money to promote the academic study of family business. They included pioneers; such as Ivan Lansberg, Aaron Levinson and George Raymond. Today, one of the leading family business associations is the Family Firm Institute (FFI) which published the first issue of the Family Business Review in 1988 and is considered the most important family business journals providing academic research.

Before the 1980s, family business was taught as a section of social studies and developed within the area of small businesses (Bird el al., 2002). Until 2004, the boundaries of the family business as a field of study were somewhat unclear and the field had no well-defined demarcations to distinguish it as a separate area of study (Sharma, 2004). Family business had to make its own way to prevent it from being perceived under the umbrella of small businesses or entrepreneurship.

Prior to 1980, the word "family business" was rarely mentioned in the literature of management studies (Astrachan, 2003). The official date of birth of family business as an academic field of study was in 1983, when the journal of 'Organisation Dynamics' issued a special issue on family business. One of the leading journals in the area of family business is the Family Business Review. The first issue was published in 1988. Furthermore, it is worth mentioning that until 2002 there was no single doctorate degree earned in the field of family business and there was no set of standards of how to be a family business consultant, despite the overarching importance of family firms to the economy (Bird et al., 2002).

Family business education is becoming a reality, more than 100 universities in the United States and throughout the world offer forums, seminars, courses, and research on family business. Where once the literature of family business consisted of a few articles and books, today an entire library could easily be devoted to what's written on family business (Aronoff, 1998).

Family business is still a relatively new field of academic study (Astrachan, 2003). According to Schulze and Gedajlovic (2010), family business research and literature remains in its infancy. This can be inferred from the fact that one of the main challenges that still face family business is that there is no consensus on a single definition of what a family business is (Sharma, 2012). This lack of consensus on a family business definition has left the field of family business open to criticism from academics and business professionals (Habbershon and Williams, 1999).

According to Ahmad (2020), there is growing awareness of the importance for skilled trained managers to ensure businesses continue to grow and innovate. Earlier studies indicate that embracing a longer-term approach to management is a critical success factor in ensuring the longevity of many Fortune 500 companies in the US (Bertrand and Schoar, 2006).

Family-owned businesses remain a key driver of global economy and contribute immensely to employment and gross domestic product (GDP) growth. Many colleges and higher education institutions are rapidly changing their course structures and curriculum (HEIs). Some believe that current family business education needs to be rethought to include curriculum that allows students to integrate family business concepts across disciplines, providing them with hard and soft skills such as decision-making, entrepreneurship, and strategy in order to return to their family work (Burch et al., 2015).

Teaching methods, means of delivery, and priority areas differ from university to institution around the world. Newer programmes have been developed in which some institutions place a greater emphasis on topics such as succession planning and communications, while others place a greater emphasis on family systems and financial management. Other institutions place a greater emphasis on leadership, governance, operations strategy, structuring, and ethical considerations (Rubenfire, 2014).

\section{CONCEPTUAL FRAMEWORK}

3.1 The pedagogy of the family business course, and how it evolved

According to Markulis, Howe, Strang (2005), Business schools are often criticized for not providing their students with an overall appreciation and understanding of the business world. Although practitioners see graduates as having good to excellent analytical skills, they feel that many students often fail to grasp the "big picture". Accordingly, the course design stressed on the practicality, and the existence of an implementable output, which can benefit the students, and their families in their practical live.

The pedagogy and methodology of delivery of the Family Business course follows the technique where the professor guides students every step of the way, throughout the whole semester - especially when needed. The professor mostly uses the adult learning technique where $\mathrm{s} / \mathrm{he}$ serves more as a facilitator, leaving space in class for the students' engagement based on the lecture the professor delivered and the information given according to the content and material. The professor also makes sure the guidelines for each assignment and presentation are very clear from day one, according to the syllabus. 
In this class, the teamwork is split into different groups who work together on the two long case presentations $(10 \%)$, the final term case report (25\%), the case progress follow up (5\%), the final case teaching notes $(5 \%)$, and the final case study presentations $(5 \%)$. And according to the schedule of the course, the in class activities are clearly mentioned and specified along with the weekly dates. As the schedule contains the lecture date, topics, readings and assignments, as well as the material students need to refer to - whether it's a video or a chapter from the textbook. The videos are not easily found, it is needed to illustrate and relate to the concept he's using in class. There is rarely a lecture held without an in class activity or exercise included since they're of extreme importance and are essential for a lively class with experiential learning. The class activities vary each class from debates to case analysis, class discussions on specific topics with sticky notes and colors, role play, real life simulations and more. The schedule is accurately detailed so that students know what they're going to do in class as well as what they need to expect and prepare for beforehand.

Over the semesters where the course was offered, there is a mission to gather and listen to students' feedback on the course and its content and methodology in order to be able to improve all its aspects as well as make adjustments to the syllabus and grading system. In Spring 2019 and Fall 2019, the feedback mechanism that followed for the course was listening to general feedback from students live in class and especially when the cases are done and submitted, the professor always checks with them whether or not those cases reflect their understanding of the course. The professor makes improvements based on the evaluation forms sent by the university every semester. What's even more important is taking into consideration what students personally tell the professor in class as s/he asks them about what they learned and whether or not they think there's room for improvement. Because not only does it help him understand and evaluate the effectiveness of the syllabus, material, and workload but it also often means a great deal to students when the professor is interested enough to know how they feel about the course and his teaching methods. It pushes them to participate and voice their opinions, even if there's some negativity to it.

To give a solid example, which changed the overall sequence of the syllabus, a student during the fall 2019 class, once turned attention towards the fact that usually the instructor divides the syllabus between the challenges discussed at the first half of the semester and the solutions we come down to at the second and final half. The professor and the rest of the students suggested that it is recommended to address each topic separately with its challenges and solutions, instead. Accordingly, when a lecture about governance is discussed, governance challenges can be addressed first and then how to resolve them right after. Which will make it easier for them to work on the cases and their teaching notes in parallel; rather than studying the challenges of each topic on its own, then after sometime going back and studying the solutions at once. It was good advice because it allowed the students to understand the whole concept efficiently, and effectively.
Consequently, in Spring 2020, a lot of changes were made to the syllabus as part of the course evolution in both the material and pedagogy as based on the students' feedback. For example, the weekly schedule was adjusted so that, a lecture about the family dynamics challenges would be given and the two immediately following lectures would be debates and discussions about the solutions for that topic and so on. And the amount of lectures given about the solution of a specific topic often varies dependent on the density of that topic. Also, the governance challenges lecture was followed by three classes that covered the solutions.

On top of that, students as case writers was something of extreme importance as part of the pedagogy and dynamics of the course. They had to perfect the case analysis in order to be able to deal with and solve the cases assigned to them whether from publishing houses or real life family business cases and situations. Most importantly, this allows them to learn how to write a case. Which is why, one or two lectures are always given in class on how to write a case. And this is always included in the syllabus, of course. Especially that students as case writers is one of the main purposes and aims of the Family Business course.

\subsection{The main topics covered in the course}

The course is covering the elementary topics which could be found in any introductory family business course, benchmarking the best practices offered globally. It addresses first an introduction about family business, including historical definitions, what makes the family business unique, different examples from family businesses in Egypt, and the rest of the world, why family business is important for the economy, myths about family business, and the theoretical foundation for understanding family business, which is mainly system theory. The second topic of the course is addressing family dynamics, where students are supposed to understand about sources of conflict in family business, genograms, participation, and commitment in family business different philosophies in family business. The third topic addresses the different challenges regarding ownership, the types of ownership, how to create effective ownership, how to separate management and ownership. The fourth topic is governance, and it addresses the different challenges that cause results from lack of governance, different types of governance tools including family meetings, board of advisers, board of directors, family council, family assembly, and family office. It also addresses the formulation of family constitution. It is worth mentioning that governance is the densest topic in the course, and it takes at least four classes. The fifth topic is the addressing the role of professionalism in family business, tackling mainly the role of non-family members in the business, and what are the challenges they might face, as well as providing useful tools to secure their sustainable contribution in the family business. The sixth topic is addressing the strategic perspective of the family business. This part is mainly concerned with the formulation of long term family business strategy, through a deep understanding of the external, and internal environment. The seventh topic is mainly concerned with developing entrepreneurial family 
business, where tools for sustaining the entrepreneurial spirit of the founders are discussed, as well as how to cater for different opinions regarding the future of the family business. Sometimes topics like emotional intelligence, leadership, and innovation, are discussed, if there is enough time left in the course.

It is important to mention that the related theoretical grounding for each topic is mentioned in every topic. Also it was found that there is a common thread related to the particularity of the Egyptian culture, in every topic. Accordingly, culture is always a challenge in the implementation of any initiative towards establishing an institutional family business.

\section{THE ASSESSMENT TOOLS OF THE COURSE}

The main assessment tools of the course stayed the same since its beginning in Spring 2017 till Spring 2020, it is mainly divided into:

- Participation is a major element in the course assessment; this is attributed to the fact that the pedagogy of the course is mainly depending on experiential learning exemplified in the class exercises, where the instructor's interference is minimal. The guidelines of participation are mentioned from day 1; so that the students are able to know about the importance of their participation in class.

- Assignments which are assessed individually through the analysis of the two medium sized cases chosen from prominent publishing houses. The students are taught about the steps of analyzing cases, and the cases are discussed thoroughly in class before submission.

- Mid-term which is assessed individually, the midterm is treated differently, considering that it's a case analysis taken out of different publishing houses, and not the textbook. The way it works is that the case is often handed and made available to the students three full days before the actual date of the midterm, so that the students would have enough time to thoroughly study and analyze the case based on the material of the course as well as the information contained in the case itself. It's similar to an open book exam, if the student doesn't wisely use that time for preparation, he's not going to be able to answer the four analytical questions in the midterm. The questions included in the midterm are usually taken out of the teaching notes that come with the original cases published in different publishing schools, houses, centers and journals around the world. The professor is the only one who can access those teaching notes, and they serve as a base students and professors could always go back to in order to learn how to run a case discussion or a case analysis in class. The case analysis midterm also serves as a way through which the professor could assess the students' individual analysis abilities; and it makes up for $20 \%$ of the final grade.

- Group case presentations, and analysis, which is assessed in groups The cases are long ones 15 to 20 pages, and are chosen from a prominent case publishing house, and the students are asked to analyze the case in a narrative format, as well as presenting it in front of the class, within the range of 20 minutes' maximum including discussion. It is worth mentioning that each case is addressing a different concept within the family business discipline.

- Case, and teaching note write up, this is the main exercise demanded from students, and it is done simultaneously throughout the whole semester. Students learn about analysis of cases, which helps to get them acquainted with the case style as a tool for experiential learning. This is followed by taking a class about how to write a case, and then discussion, and critique of several cases from previous semesters are posted over the blackboard.

- Case, and teaching note, progress follow up', this a rigorous exercise which is done three times throughout the semester, to ensure the quality of the case write up, and teaching note. The instructor is acting like a reviewer where $\mathrm{s} / \mathrm{he}$ is supposed to address all of the relevant aspects to case writing starting from formatting, till quality of writing, and expression of the main dilemma, as well providing the theoretical background for the suggested questions in the teaching note.

- Final case study presentation, this assessment is done during the exam day, and it is mainly done to measure the degree of understanding of the students regarding the concepts learned throughout the whole semester. A portion of the time is allocated after the presentation for questions, and answers, to assure that each student was able to comprehend all of the concepts of the family business course.

\section{THE GUIDELINES AND RUBRICS OF THE COURSE}

The course guidelines are one of the most important elements of a syllabus. Hence, students have to pay attention to them while reading the syllabus to know the basis that they are going to be taught and graded upon.

Class participation guidelines are defined and highlighted, so if a student by the end of the semester would wonder why he/she got a low grade, they should go back to the guidelines where it states that "class participation carries a high weight in the course grade and students will have to earn these grades." The scale of grading students' participation is also stated; where "excellent participation" is given to students who constantly share their ideas and provide major insights and direction for class discussions. Whereas "good contribution" is given to students to provide good insights and might sometimes direct class discussions, their critical and analytical thinking is evident but without a proof of wider understanding of the topic. In that respect, "fair participation" is given to students who sometimes express their ideas and provide some level of useful insights but they do not direct class discussions. The least assessment is "unsatisfactory participation" which is given to students who rarely contribute in classes and provide few insights into class discussions, in addition they never prove critical or analytical thinking aspects. 
- Each week students are required with your Case write up guidelines: the students are taught how to write a case study from scratch, where all the guidelines and important points are highlighted. The size and format of the page are also mentioned, and the word count mentioned. After finalizing the case as per all the guidelines and the instructions mentioned by the instructor in the syllabus, a soft copy in Word document as well as a PDF file should be sent to the professor. The instructor explains that there is a probability of publishing students' cases later on. Below are the guidelines in details

- Confidentiality agreement will be granted to all teams

- There will be a competition among the participants; a prize will be given to the winning team.

- Every team will have a nominated leader.

- Each team will present the final case in 20 minutes including discussion.

- The groups will be required to work in their projects simultaneously and in parallel with the sequence of the lectures.

- Group to work on a task. Teams must upload your work on to Blackboard under the relevant group under file exchange by the end of the day of the class activity.

- Each team will present the detailed written project (hard copy and soft copy) using a normal binder and transparent cover.

- Individual differences will be assessed according to the written section of each member

- Every team is composed of 4-6 students. Each student from every group will highlight her/his individually written part of the project. Each member will also be individually evaluated on his part of the final presentation.

- The accepted project format: font type: Times new Roman / Size: 11 / single-spaced. Double space between the title and the first line of the text. Margins: 1 inch on all sides

- The size of the project is minimum 17 pages to provide complete details not including references and cover page, this means around 7000 words

- Headings font size 14

- A cover page including the names of the team as well as the title of the business is a must

- Soft copy in word and PDF will be sent to the instructor

- Teams will be provided with thorough feedback including comments.

The steps of any case study starts by an abstract that does not exceed 250 words and the case writer provides an overview of the case to help the reader know if this case is relevant to their teaching purposes or not. The abstract is then followed by an opening paragraph. It is worth mentioning that any case must have a storyline to grasp the reader's attention and to cover all the aspects of the case. Hence, the opening paragraph is, more or less, where the story starts, with an introduction about the company, its background and the dilemma faced. The company background should be precisely mentioned as per its factors, to describe the company's size and its progress since start-up, to identify the market position as well as the financial figures. The issue that faced students while gathering financial figures, is that the families who owned the business did not prefer to give them their financial figures since it is very sensitive, hence they would only give trends. The case writer here also mentions the product or the service that this company provides to the customers and identifies the target customers too. And most importantly, to highlight the competitive strategy. Then comes a very important part, which is the family challenges. It is important to mention that the sequence of the steps of this point is the same sequence of the course. This makes it easier for students because after the professor explains a certain point, he/she can apply it to their case study. Afterwards, the family challenges are covered thoroughly, starting by the family dynamics challenge and description of the family dynamics in a narrative way and describing the relations in a genogram, then the ownership challenges should be discussed where the case writer describes the current ownership structure using a diagram to be posted in the exhibit/appendix and to describe the challenges originating from the current ship and to highlight the ownership structure after separation, if separation had occurred. Then comes the governance and professionalism challenge followed by the succession challenge. After describing the challenges and elaborating them in detail, the industry overview should be explained. For instance, forces of competition have to be identified, suppliers and supply chain [if relevant] and any other piece of information that might help the reader better understand the context. And as mentioned before, any case ends with a dilemma where the reader would be placed in the shoes of the protagonist and needs to make a decision or plan some action, and this is followed by a closing paragraph that reiterates the decision and dilemma and highlight the significance of the situation for the company, its stakeholders and the protagonist. Some basic guidelines are then stated for the students to follow including but not restricted, to always write in the past tense, and to avoid fictional cases, etc.

Teaching note guidelines: After finalizing the case, there has to be a teaching note, also written by the groups, to accompany the case study. The students are provided by guidelines to help them while with its structure. The first step mentioned is writing a case synopsis, which is quite similar to the abstract previously written in the case itself. This is followed by the assignment questions that are not necessarily the same in each case. The general advice in regards to this is not to write more than 4 to 5 questions, this is because the questions should have in-depth rather than in-breadth. The choice of questions should encompass two direct questions that can be extracted from the case, and three questions that test critical thinking. Answers for the latter could vary because each person has his/her own opinion and way of thinking. The professor also asks for any reading or material that has been used by the students while writing the case. The background reading may typically include conceptual or analytical framework required to be able to prepare the case and are part of the course material and syllabus assigned to students. Some of these readings may have been explained by the professor in previous class sessions while others may be provided for self-learning and to facilitate the case preparation. In addition to that, the background readings help to situate the 
case learning within the overall conceptual framework of the academic discipline being taught as well as the research literature in the discipline. Additionally, there are two optional additions by the end of the teaching notes; the exhibits as well as the multimedia content, if there's any. Throughout the academic semester, the group meets with the professor three times for the progress report to constantly update the professor so that he knows where each group stands and if any are facing challenges that need to be addressed.

- Case presentation guidelines: By the end of the academic semester, each team is required to do a presentation that has guidelines. A panel is usually present during the presentation and they conduct a competition between the presenting teams.

- Case analysis guidelines: In order to be proficient in writing cases, students are required to understand "How to analyze a case". The case analysis steps are explained to students in 10 points; gaining familiarity with the events of the case, identify the key players of the case, explore the timeline of the events. These first three points can be easily done through reading the case study. Then comes the fourth step which is to identify the main challenges faced, such a governance or succession issue, then if there is enough information the student is required to conduct a SWOT analysis. Later on, the case ends with some available alternatives that the student has to identify. Sometimes, a case might not end by available alternatives so the students might think of available alternatives to fix the challenges. These alternatives take us to the next step which is recommending solutions for the challenges faced, and usually any solution has pros and cons, so the student chooses one solution for the final decision and conducts an action plan upon that. If a student is not focused on the materials and the explanation of these steps, he/she won't be able to carry on with all the steps, or might cover them without emphasis. There are guidelines for the assignments questions' answers too; as the case writer presents detailed answers to the assignment and discussion questions of the case. The guidelines state that the answers should demonstrate the required analysis that students should ideally learn to perform in order to arrive at well-grounded solutions to the dilemma rather than only submitting model answers. And both quantitative as well as qualitative analyses are desirable according to the extent of analysis that the case allows. This section does not usually provide model answers, it presents the necessary facts and analysis in addition to a possible answer to the case problem. It is also possible that the case writer outlines the alternative analysis avenues that are equally valid for the case at hand, even though he/she may present only one approach in detail. Case writers can also make use of the conceptual frameworks to guide and organize the case analysis. As for the structure, the case analysis and answers should be presented in the same structure and order as the discussion plan in the teaching plan section. Case studies that students write, along with their teaching notes, are later on used in future classes.
- Mid-term guidelines: as for the midterm, the exam is in the form of questions that are related to a case given to students 3 days in advance, and the student is supposed to answer the questions within the allocated class time, 75 minutes, which gives them time to thoroughly read the case and highlight any important points they read, accordingly a printed copy of the case with some comments can be brought to the exam. The guidelines of the midterm exam state that the exam questions test the student's understanding of the course, thus it is recommended that the student would read the material in advance. It is worth mentioning that the midterm case study is given to students three days prior to the exam, Afterwards, all answers should be submitted over Blackboard and plagiarism is tested, and if detected the exam will be cancelled.

- Reflection paper guidelines: Throughout the academic semester, four experienced guest speakers from different family businesses are invited to the class. Some of them have solved any dilemma or challenge faced and others are still going through them, the latter represents more than $90 \%$ of the family businesses in Egypt. The instructor tried to balance between guest speakers who come from wellestablished family businesses, and others who might be still facing challenges. The impact of young guest speakers on the students is usually higher than older family businesses owners, because they feel close to them and can easily relate to their lives. After the guest speaker's talk, students are required to write a reflection paper that has guidelines. These guidelines state that the student must describe the talk as well as its relevance to the course, and to highlight any challenges that were identified, and most importantly, to mention the lessons learned to to write if they have any further recommendations.

- Family business case choice criterion guidelines: Students are usually confused while choosing the family business that they are going to study, accordingly, a criterion for the chosen family business was provided to them. Main points of the criteria state that the business chosen has to relate to one of the students' families so that they would easily access the information, this helps to enhance the experiential learning where students can later on apply the theoretical concepts they have learned in that course into real life.

- Guest speaker choice guidelines: Apart from that, students were offered an incentive to personally invite a guest speaker from their side in return for a $1.5 \%$ of the participation grade. And this incentive served as a motivation for students. There was a criterion for choosing the family business guest speakers (in order for the talk itself to be rich. The criteria entailed that the experienced speaker should belong to one of the students' families for easy access and contact. S/he should also have been there for at least two generations. The business $\mathrm{S} /$ he's going to be talking about should be facing challenges due to family dynamics, since that's basically what the whole course initially revolves around. S/he should also be of vast knowledge about the business and family dynamics. Not to mention the need for him to be willing to share information and pass recommendations by students. 
As for the rest of the guidelines, attending the classes promptly is highlighted in addition to reading the assigned material prior to coming to class to maximize the benefit from the given exercises and provide the participation grade.

Regarding exams and assignments, makeup exams are only available under certain exceptional circumstances. And all assignments or group work have to be submitted through Blackboard. Students' behavior in class is also entailed, where it mentions "unacceptable and distracting behavior during class such as chatting with neighbors, use of laptops, phones and other devices will result in negative participation grades."

In a related context, rubrics are of extreme importance to the students. Each assignment and exercise in the Family Business course has its rubrics, in order for each student to rightfully be provided with the rules and feedback necessary. The rubrics used are mentioned below:

- Case analysis rubric which contains the coverage of eye points, the quality of analysis, the depth and applicability of recommendations and abiding by case analysis guidelines in order to avoid any complications and misunderstandings the students might face during the analysis. And most importantly, so they could have everything that needs to be done loud and clear right in front of them and when/if they lose points, they could go back and know which point they failed to cover from the rubric.

- Individual cases assignments rubric, case discussions are always held in class before the due dates to ensure students thoroughly read and understand what they need to work on and submit. And a rubric was also set for those case discussions and it includes: The coverage of key points, the quality of analysis, the depth and applicability of recommendations, the questions and answers.

- The midterm rubric is a bit different than all the other ones as it focuses more on the logical and elaborative responses. It includes completion of the answers, quality of responses, relevancy to the course material, scientific rigor, and providing logic recommendations. It was noticed that there is a recurring weakness in the quality of responses, in terms of elaboration and linkage between different aspects. Mainly because those two points require a thorough read and understanding of the case. And of course, a well preparation in the three days prior to the midterm. If the student is well prepared and if he thoroughly read and analyzed the case in the three days prior to the midterm, he could easily expect the questions that are of major importance to be included in the midterm. Hence, he'll answer in no time and with no difficulties whatsoever. It's also worth mentioning that it's about both quality and quantity. Because the quality of responses depends on the elaboration. Meaning that if there's no quantity, then there's no quality and vice versa.

- Reflection paper rubric that is made especially for the guest speakers' talks that students are required to reflect on. And that rubric includes the description of the discussion, the explanation of the personal experience, the explanation of the relevancy of the course, the lessons learned and the compliance with the guidelines.

- Family business case and teaching note rubric, the rubric includes: Complying with guidelines, providing valid evidence for the content [Primary and secondary data], quality of content [Elaboration and relevance], and stringency of language used [grammar, syntax, orthography]. It rarely ever happens that a student asks for his assessment rubric after the final grade is posted. And the reason for that is that throughout the semester, three progress reports are submitted and shared with the professor. Meaning that the professor is always step by step with the student, and even the document of both the cases and the teaching notes are shared and revised with him from the very beginning.

- Final case presentations rubric is divided between technicalities and presentation skills with the grading weight of the content of the presentation itself being heavier; as it includes the coverage of key points, the quality of analysis, the depth and applicability of recommendations, commitment to time, presentation organization, body language, illustrations, storytelling, questions and answers and the teamwork and balance.

- By the end of the semester a competition is conducted in collaboration with a prominent consulting company with vast experience in the field of Family business, where along with the professor, a panel consisting of two people related to the competition often attend the case presentations to judge and assess the students; a printed copy of the case presentation rubric is also distributed to each one of them so that they could grade the case presentation based on their own opinion in relevance to the rubric. And in the end, the three judges come together to compare what they individually wrote down to make the final call. Judges often arrive at an agreement and decision. The winning team is offered an internship at the chosen company that attends the said case presentations. And it is worth mentioning that so far, two students ended up being employed due to winning the competition and interning as a result in the company.

\section{CONCLUSION}

Family business education is still finding its own way to establish itself between the traditional business subjects. This paper presented the experience at the American University in Cairo the course went through several stages of refinements either in the content of the course or the way of teaching. Students who studied this course get a great benefit through being aware of several issues related to family business which will help them a lot deal with them. This applies to those students who will join their family business or who will be hired by family controlled companies, and they are not family members. At the end, it is expected that this research case will boost the awareness of family business as a subject and to enlist the course as a requirement in other Egyptian schools of business. The outcome of the course since spring 2017 has been highly satisfactory; since it fills a gap within the family businesses through the case write-ups delivered in 
collaboration with students, and published in prominent journals (see exhibit 1).

It is worth saying that the journey is still in the evolution phase, and that the learning experience is evolving. There some lessons to be learned from the evolution of the course, and the real life examples addressed since spring 2017, whether from teaching cases studies, reflections from guest speakers, practical workshops, and private consultations, and those lessons are: first each family business is a different case by itself; accordingly, there is no one fit all solution for all of the challenges faced. Second there is a strong relationship between the success of family business and the culture of the organization. Third there is a great need to work on the governance, and succession aspects of family business. Fourth there is a need for Egyptian family businesses to enhance their understanding about different legal forms of family businesses. Finally, there is a considerable challenge in implementation of all the foundations of the family business institutionalization.

Table 1: Recent case titles with publishing details.

\begin{tabular}{|c|c|c|c|c|c|}
\hline \# & Case title & $\begin{array}{l}\text { Publication/con } \\
\text { ference venue }\end{array}$ & Status & Award & $\begin{array}{l}\text { Expected year of } \\
\text { publication/ year of } \\
\text { publication }\end{array}$ \\
\hline 1 & $\begin{array}{l}\text { El Batraa Manufactures for } \\
\text { Chemicals and Paint }\end{array}$ & $\begin{array}{l}\text { Emerald } \\
\text { Emerging } \\
\text { Markets Case } \\
\text { Studies }\end{array}$ & Published & & 2021 \\
\hline 2 & $\begin{array}{l}\text { The New Era Brothers for Trade: } \\
\text { The Problematic Evolution of a } \\
\text { Family Business } \\
\text { Within Several Industries. }\end{array}$ & Ivey publishing & $\begin{array}{l}\text { In the } \\
\text { reviewing } \\
\text { phase }\end{array}$ & $\begin{array}{l}\text { Second prize award for } \\
\text { the Emerald (emerald } \\
\text { emerging market case } \\
\text { studies)/KCC } \\
\text { (Khazindar case } \\
\text { clearing) }\end{array}$ & 2021 \\
\hline 3 & $\begin{array}{l}\text { United Group: Exploring the } \\
\text { prospects of The Future. }\end{array}$ & $\begin{array}{l}\text { Emerald } \\
\text { Emerging } \\
\text { Markets Case } \\
\text { Studies }\end{array}$ & $\begin{array}{l}\text { In the } \\
\text { reviewing } \\
\text { phase }\end{array}$ & & 2021 \\
\hline 4 & $\begin{array}{l}\text { Power Jet: An Uncertainty of } \\
\text { Legacy }\end{array}$ & Case focus & $\begin{array}{l}\text { In the } \\
\text { reviewing } \\
\text { phase }\end{array}$ & & 2021 \\
\hline 3 & $\begin{array}{l}\text { Technology Park Company: } \\
\text { Harvesting the Fruits of a Family } \\
\text { Business }\end{array}$ & Case Centre & Published & $\begin{array}{l}\text { European foundation } \\
\text { for Management } \\
\text { Development award } \\
\text { (EFMD) } 2019 \text { for } \\
\text { teaching cases in the } \\
\text { field of Family } \\
\text { business. }\end{array}$ & 2019 \\
\hline 4 & $\begin{array}{l}\text { The Dispersion of a Realm: } \\
\text { Alumin for Trading }\end{array}$ & Case Centre & Published & & 2020 \\
\hline 5 & $\begin{array}{l}\text { ElectroMitry: } 45 \text { Years Serving } \\
\text { Technology in Egypt. }\end{array}$ & Case Centre & Published & & 2020 \\
\hline 6 & Nourpack: Chaos in the Future & Case Centre & Published & & 2019 \\
\hline
\end{tabular}




\begin{tabular}{|c|c|c|c|c|}
\hline 7 & MOG for metal manufacturing. & Case Centre & Published & 2019 \\
\hline 8 & $\begin{array}{l}\text { Quadratics Pharma: } \\
\text { Understanding Family Challenges } \\
\text { in Businesses }\end{array}$ & $\begin{array}{l}\text { Sage business } \\
\text { cases }\end{array}$ & Published & 2021 \\
\hline 9 & $\begin{array}{l}\text { Stone Builders for Construction: } \\
\text { Thirty Grandchildren, One } \\
\text { Business. }\end{array}$ & $\begin{array}{l}\text { Sage business } \\
\text { cases }\end{array}$ & Published & 2021 \\
\hline 10 & $\begin{array}{l}\text { Egyptian Tires and Batteries } \\
\text { Importers. }\end{array}$ & & $\begin{array}{l}\text { Conference } \\
\text { proceeding } \\
\text { within the } \\
\text { Family } \\
\text { business in the } \\
\text { Arab world } \\
\text { conference } \\
\text { (FBAW) }\end{array}$ & 2021 \\
\hline 11 & $\begin{array}{l}\text { Textile Egypt Company: } \\
\text { Understanding Family Challenges }\end{array}$ & & $\begin{array}{l}\text { Conference } \\
\text { proceeding } \\
\text { within the } \\
\text { Family } \\
\text { business in the } \\
\text { Arab world } \\
\text { conference } \\
\text { (FBAW) }\end{array}$ & \\
\hline
\end{tabular}

\section{REFERENCES}

[1] Ahmad, T. (2020). Universities preparing students for future challenges of family business enterprises. World Journal of Entrepreneurship, Management and Sustainable Development.

[2] Aronoff, C. E. (1998). Megatrends in family business. Family business review, 11(3), 181-186.

[3] Astrachan, J. H. (2003). Commentary on the Special Issue: The Emergence of a Field. Journal of Business Venturing, 18(5), 567-572.

[4] Bertrand, M. and Schoar, A. (2006), "The role of family in family firms", The Journal of Economic Perspectives, Vol. 20 No. 2, pp. 73-96.

[5] Bird, Barbara, Welch Harold, Astrachan Joseph, and Pistrui David., 2002. Family Business Research: The Evolution of an Academic Field. Family Business Review, 15(4), pp.337-350.

[6] Burch, G.F., Batchelor, J.H., Burch, J.J. and Heller, N.A. (2015), "Rethinking family business education", Journal of Family Business Management, Vol. 5 No. 2, pp. 277-293.

[7] Carney, M. (2005). Corporate governance and competitive advantage in family-controlled firms. Entrepreneurship theory and practice, 29(3), 249-265.

[8] Chrisman, J. J., Chua, J. H., \& Sharma, P. (2005). Trends and directions in the development of a strategic management theory of the family firm. Entrepreneurship theory and practice, 29(5), 555-575.

[9] Carney, M. (2005). Corporate governance and competitive advantage in family-controlled firms. Entrepreneurship theory and practice, 29(3), 249-265.

[10] Carney, M. (2005). Corporate governance and competitive advantage in family-controlled firms. Entrepreneurship theory and practice, 29(3), 249-265.

[11] Chrisman, J. J., Chua, J. H., \& Sharma, P. (2005). Trends and directions in the development of a strategic management theory of the family firm. Entrepreneurship theory and practice, 29(5), 555-575.

[12] Chrisman, J. J., Chua, J. H., Pearson, A. W., \& Barnett, T. (2012). Family involvement, family influence, and familycentered non-economic goals in small firms. Entrepreneurship theory and practice, 36(2), 267-293.

[13] Chua, J. H., Chrisman, J. J., \& Sharma, P. (1999). Defining the family business by behavior. Entrepreneurship theory and practice, 23(4), 19-39.

[14] Dawson, A., \& Mussolino, D. (2014). Exploring what makes family firms different: Discrete or overlapping constructs in the literature?. Journal of Family Business Strategy, 5(2), 169-183.

[15] Habbershon, T.G. \& Williams, M.L. (1999). A resource-Based Framework for Assessing the Strategic Advantages of Family Firms. Family Business Review, 12(1), pp.1-25.

[16] Handler, W. C. (1994). Succession in family business: A review of the research. Family business review, 7(2), 133-157. 
[17] Markulis, P. M., Howe, H., \& Strang, D. R. (2005). Integrating the business curriculum with a comprehensive case study: A prototype. Simulation \& Gaming, 36(2), 250-258.

[18] Rubenfire, A. (2014), "B-schools Take on the Family Business", Wall Street Journal, July 3, p. 1, Business Source Complete, Ipswich, MA, (accessed 18 September 2018).

[19] Sharma, P., Hoy, F., Astrachan, J. H., \& Koiranen, M. (2007). The practice-driven evolution of family business education. Journal of Business Research, 60(10), 1012-1021.

[20] Sharma, P. (2004). An Overview of the Field of Family Business Studies: Current Status and Directions for the Future. Family business Review, 17(1), pp.136.

[21] Sharma, P., Chrisman, J. J., \& Gersick, K. E. (2012). 25 years of family business review: Reflections on the past and perspectives for the future.

[22] Schulze, W. S., \& Gedajlovic, E. R. (2010). Whither Family Business. Journal of Management Studies, 47(2), pp.191-204.

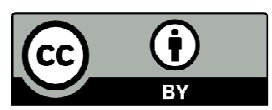

(C) 2021 by the Dr. Ashraf Sheta and Dr. Ahmed El Gallad. Submitted for possible open access publication under the terms and conditions of the Creative Commons Attribution (CC BY) license (http://creativecommons.org/licenses/by/4.0/). 